\title{
Soil greenhouse gas fluxes from tropical coastal wetlands and alternative agricultural land uses
}

\author{
Naima Iram ${ }^{1}$, Emad Kavehei ${ }^{1}$, Damien T. Maher ${ }^{2}$, Stuart E. Bunn ${ }^{1}$, Mehran Rezaei Rashti ${ }^{1}$, \\ Bahareh Shahrabi Farahani $^{1}$, and Maria Fernanda Adame ${ }^{1}$ \\ ${ }^{1}$ Australian Rivers Institute, Griffith University, Nathan, QLD, 4111, Australia \\ ${ }^{2}$ School of Environment, Science and Engineering, Southern Cross University, Lismore, NSW, 2480, Australia
}

Correspondence: Naima Iram (naima.iram@griffithuni.edu.au)

Received: 6 February 2021 - Discussion started: 19 March 2021

Revised: 24 August 2021 - Accepted: 24 August 2021 - Published: 16 September 2021

\begin{abstract}
Coastal wetlands are essential for regulating the global carbon budget through soil carbon sequestration and greenhouse gas ( $\mathrm{GHG}-\mathrm{CO}_{2}, \mathrm{CH}_{4}$, and $\mathrm{N}_{2} \mathrm{O}$ ) fluxes. The conversion of coastal wetlands to agricultural land alters these fluxes' magnitude and direction (uptake/release). However, the extent and drivers of change of GHG fluxes are still unknown for many tropical regions. We measured soil GHG fluxes from three natural coastal wetlands - mangroves, salt marsh, and freshwater tidal forests - and two alternative agricultural land uses - sugarcane farming and pastures for cattle grazing (ponded and dry conditions). We assessed variations throughout different climatic conditions (dry-cool, dry-hot, and wet-hot) within 2 years of measurements (2018-2020) in tropical Australia. The wet pasture had by far the highest $\mathrm{CH}_{4}$ emissions with $1231 \pm$ $386 \mathrm{mg} \mathrm{m}^{-2} \mathrm{~d}^{-1}$, which were 200 -fold higher than any other site. Dry pastures and sugarcane were the highest emitters of $\mathrm{N}_{2} \mathrm{O}$ with $55 \pm 9 \mathrm{mg} \mathrm{m}^{-2} \mathrm{~d}^{-1}$ (wet-hot period) and $11 \pm 3 \mathrm{mg} \mathrm{m}^{-2} \mathrm{~d}^{-1}$ (hot-dry period, coinciding with fertilisation), respectively. Dry pastures were also the highest emitters of $\mathrm{CO}_{2}$ with $20 \pm 1 \mathrm{~g} \mathrm{~m}^{-2} \mathrm{~d}^{-1}$ (wet-hot period). The three coastal wetlands measured had lower emissions, with salt marsh uptake of $-0.55 \pm 0.23$ and $-1.19 \pm 0.08 \mathrm{~g} \mathrm{~m}^{-2} \mathrm{~d}^{-1}$ of $\mathrm{N}_{2} \mathrm{O}$ and $\mathrm{CO}_{2}$, respectively, during the dry-hot period. During the sampled period, sugarcane and pastures had higher total cumulative soil GHG emissions $\left(\mathrm{CH}_{4}+\mathrm{N}_{2} \mathrm{O}\right)$ of 7142 and $56124 \mathrm{CO}_{2 \text {-eq }} \mathrm{kgha}^{-1} \mathrm{yr}^{-1}$ compared to coastal wetlands with 144 to $884 \mathrm{CO}_{2 \text {-eq }} \mathrm{kg} \mathrm{ha}^{-1} \mathrm{yr}^{-1}$ (where $\mathrm{CO}_{2 \text {-eq }}$ is $\mathrm{CO}_{2}$ equivalent). Restoring unproductive sugarcane land or pastures (especially ponded ones) to coastal wetlands could provide significant GHG mitigation.
\end{abstract}

\section{Introduction}

Coastal wetlands are found at the interface of terrestrial and marine ecosystems and account for $10 \%$ of the global wetland area (Lehner and Döll, 2004). They are highly productive and provide various ecosystem services such as water quality improvement, biodiversity, and carbon sequestration (Duarte et al., 2013). For instance, mangroves can accumulate 5 times more soil carbon than terrestrial forests (Kauffman et al., 2020). However, the high productivity and anoxic soil conditions that promote carbon sequestration can also favour potent greenhouse gas (GHG) emissions, including $\mathrm{CO}_{2}, \mathrm{CH}_{4}$, and $\mathrm{N}_{2} \mathrm{O}$ (Whalen, 2005; Conrad, 2009).

The GHG emissions in coastal wetlands primarily result from microbial processes in the soil-water-atmosphere interface (Bauza et al., 2002; Whalen, 2005). The emission of $\mathrm{CO}_{2}$ is a result of respiration, where fixed carbon by photosynthesis is partially released back into the atmosphere (Oertel et al., 2016). Emissions of $\mathrm{CH}_{4}$ result from anaerobic and aerobic respiration by methanogenic bacteria, mostly in waterlogged conditions (Angle et al., 2017; Saunois et al., 2020). Finally, $\mathrm{N}_{2} \mathrm{O}$ emissions are caused by denitrification in anoxic conditions and nitrification in aerobic soils, both driven by nitrogen content and soil moisture (Ussiri and Lal, 2012). Thus, the total GHG emissions from a wetland are driven by environmental conditions that favour these microbial processes, all of which result in highly variable emissions from wetlands worldwide (Kirschke et al., 2013; Oertel et al., 2016).

Despite potentially high GHG emissions from coastal wetlands, these are likely to be lower than those from alterna- 
tive agricultural land use (Knox et al., 2015), which emit GHGs from their construction and throughout their productive lives. Firstly, when wetlands are converted to agricultural land, the oxidation of sequestered carbon in the organicrich soils releases significant amounts of $\mathrm{CO}_{2}$ (Drexler et al., 2009; Hooijer et al., 2012). Secondly, removing tidal flow and converting coastal wetlands to freshwater systems, such as during the creation of ponded pastures, dams, or agricultural ditches, can result in very high $\mathrm{CH}_{4}$ emissions (Deemer et al., 2016; Grinham et al., 2018; Ollivier et al., 2019). For instance, agricultural ditches contribute up to $3 \%$ of the total anthropogenic $\mathrm{CH}_{4}$ emissions globally (Peacock et al., 2021). Finally, the use of fertilisers significantly increases $\mathrm{N}_{2} \mathrm{O}$ emissions (Rezaei Rashti et al., 2015). Thus, emissions of GHGs from land use change can be mitigated through the reversal of these activities, for instance, reduction in fertiliser use and the reinstallation of tidal flow on unused agricultural land (Kroeger et al., 2017; Rezaei Rashti et al., 2015).

This study measured the annual GHG fluxes $\left(\mathrm{CO}_{2}, \mathrm{CH}_{4}\right.$, and $\mathrm{N}_{2} \mathrm{O}$ ) from three natural coastal wetlands (mangroves, salt marsh and freshwater tidal forests) and two agricultural land use sites (sugarcane plantation and pasture) in tropical Australia. The objectives were to assess the difference in GHG fluxes throughout different seasons that characterise tropical climates (dry-cool, dry-hot, and wet-hot) and identify environmental factors associated with these GHG fluxes. These data will inform emission factors for converting wetlands to agricultural land uses and vice versa, filling in a knowledge gap identified in Australia (Baldock et al., 2012) and tropical regions worldwide (IPCC, 2013).

\section{Materials and methods}

\subsection{Study sites}

The study area is located within the Herbert River catchment in Queensland, northeast Australia (Fig. 1a). The region has a tropical climate with a mean monthly minimum temperature from 14 to $23^{\circ} \mathrm{C}$ and mean monthly maximum temperature from 25 to $33^{\circ} \mathrm{C}$ (Australian Bureau of Meteorology, ABM, 2020; 1968-2020; Sect. S4 in the Supplement). The average rainfall is $2158 \mathrm{~mm} \mathrm{yr}^{-1}$, with the highest values of $476 \mathrm{~mm}$ during February (ABM, 2020; 1968-2020; Sect. S4). The Herbert basin covers $9842 \mathrm{~km}^{2}$, from which $56 \%$ is grazing, $31 \%$ is conserved wetlands and forestry, $8 \%$ is sugarcane, and $4 \%$ is other land uses (Department of Environment and Science, Queensland, 2013). Wetlands in this region were heavily deforested in the last century (1943-1996) due to rapid agricultural development, primarily for sugarcane farming (Griggs, 2018). Before clearing, the land was mostly covered by rainforest and coastal wetlands, mainly Melaleuca forest, grass, and sedge swamps (Johnson et al., 1999).
We selected five sites, including three natural coastal wetlands (Fig. 1) - a mangrove forest $\left(18^{\circ} 53^{\prime} 42^{\prime \prime} \mathrm{S}\right.$, $\left.146^{\circ} 15^{\prime} 51^{\prime \prime} \mathrm{E}\right)$, a salt marsh $\left(18^{\circ} 53^{\prime} 43^{\prime \prime} \mathrm{S}, 146^{\circ} 15^{\prime} 52^{\prime \prime} \mathrm{E}\right)$, and a freshwater tidal forest $\left(18^{\circ} 53^{\prime} 45^{\prime \prime} \mathrm{S}, 146^{\circ} 15^{\prime} 52^{\prime \prime} \mathrm{E}\right)-$ and two common agricultural land use types of the region - a sugarcane crop $\left(18^{\circ} 53^{\prime} 44.6^{\prime \prime} \mathrm{S}, 146^{\circ} 15^{\prime} 53.2^{\prime \prime} \mathrm{E}\right)$ and a pasture for fodder grazing. The pasture had different levels of inundation: some areas were covered with shallow ponds (50-100 cm depth); some were wet (hereafter "wet pasture"; $18^{\circ} 43^{\prime} 8^{\prime \prime} \mathrm{S}, 146^{\circ} 15^{\prime} 50^{\prime \prime} \mathrm{E}$ ); and others were dry (hereafter, "dry pasture"; $18^{\circ} 43^{\prime} 7^{\prime \prime} \mathrm{S}, 146^{\circ} 15^{\prime} 50^{\prime \prime} \mathrm{E}$ ). The natural coastal wetlands and the sugarcane site were located within the same property $<200 \mathrm{~m}$ apart at Insulator Creek (Fig. 1b), while the ponded pasture was $20 \mathrm{~km}$ north at Mungalla Station (Fig. 1a). The mangroves were dominated by Avicennia marina with a few plants of Rhizophora stylosa, and the salt marsh was dominated by Suaeda salsa and Sporobolus spp. Landwards, the freshwater tidal forest, a wetland commonly known as "tea tree swamp", was dominated by Melaleuca quinquenervia trees. While the mangroves and salt marsh are directly submerged by tides $(5-30 \mathrm{~cm})$, the freshwater tidal forest is indirectly affected by tidal fluctuations, such as during large spring tides, when tidal water can push groundwater above the forest thus forming "supra-tidal" wetlands. The coastal wetlands were adjacent to a sugarcane farm of $\sim 110$ ha (Fig. 1b). The sugarcane is fertilised once a year with urea at a rate of $135 \mathrm{~kg} \mathrm{Nha}^{-1}$ and harvested during May-June, and the foliage is left on the soil surface (trash blanket) after harvest. The ponded pastures in Mungalla Station comprise a 250 ha farm and support $\sim 900$ cattle by providing fodder during dry periods. The selected ponded pastures were covered by Eichhornia crassipes (water hyacinth) and Hymenachne amplexicaulis (Fig. 1g-h). Each of the five sites was sampled during three periods: dry-cool (May-September), dry-hot (October-December), and wethot (January-April; Table 1). During each time period, soil physicochemical properties and GHG fluxes were measured as detailed below.

\subsection{Soil sampling and analysis of physicochemical properties}

Soil physicochemical characteristics were measured in composite soil samples next to each gas chamber location $(n=5$; $0-30 \mathrm{~cm}$ ) for all study sites during the dry-hot season. The samples were obtained by inserting an open steel corer to a depth of $30 \mathrm{~cm}$; the core was divided into three depths: $0-10,10-20$, and $20-30 \mathrm{~cm}$. Soil samples were oven-dried at $105^{\circ} \mathrm{C}$ for $48 \mathrm{~h}$ to determine volumetric water content through gravimetric analysis. The volumetric water content was divided by total soil porosity to determine water-filled pore space (WFPS). Total soil porosity was calculated using an equation from Rezaei Rashti et al. (2015; Eq. 1):

total soil porosity $=1-\left[\frac{\text { soil bulk density }\left(\mathrm{mg} \mathrm{cm}^{-3}\right)}{2.65}\right]$. 

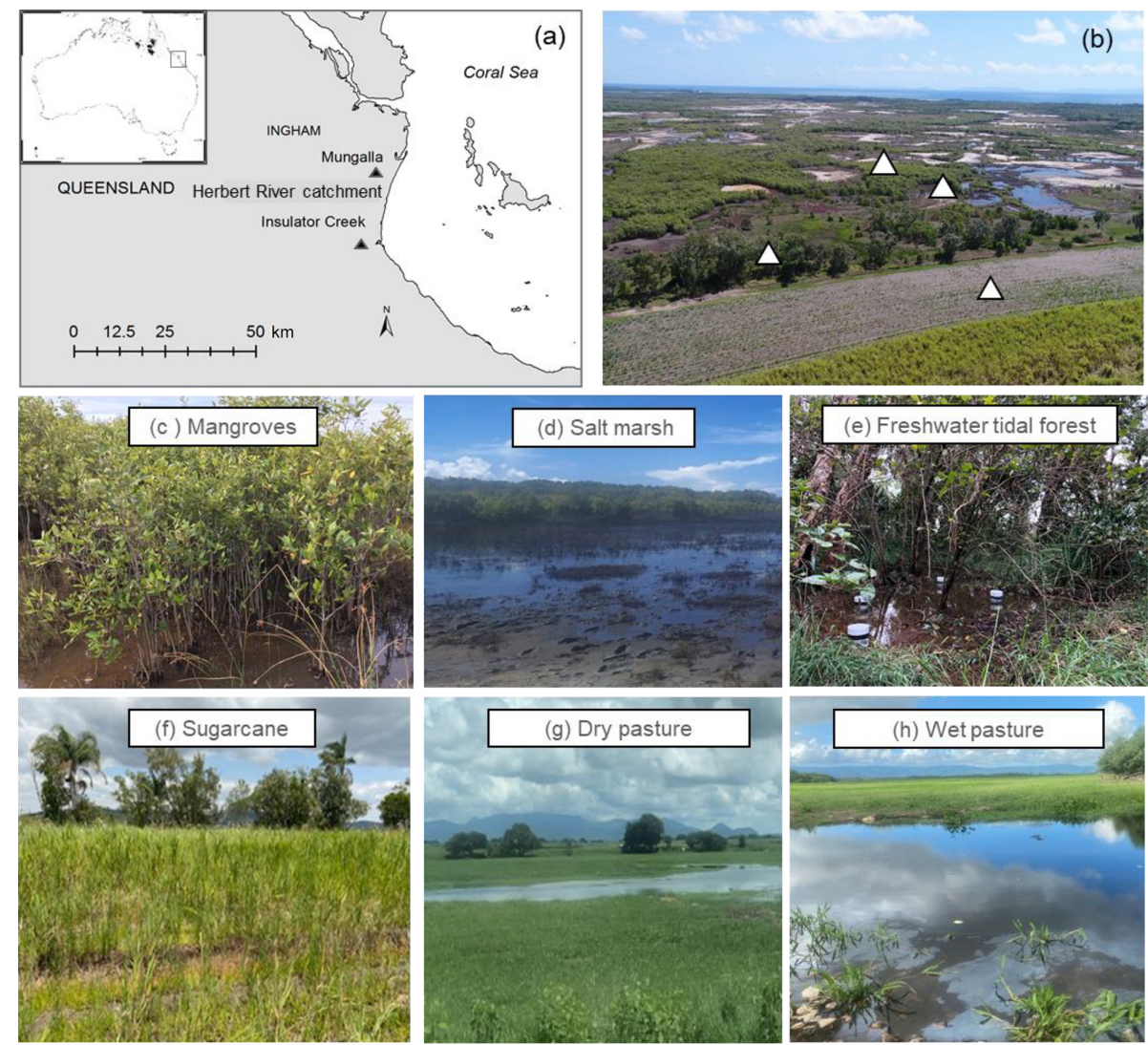

Figure 1. (a) Location of sampling sites (Insulator Creek and Mungalla) in the Herbert River catchment, northeast Australia; (b) natural wetlands adjacent to sugarcane in Insulator Creek and sampling locations; and (c) mangroves, (d) salt marsh, (e) freshwater tidal forest, (f) sugarcane, (g) dry pasture, and (h) wet pasture. Pictures by Naima Iram and Maria Fernanda Adame.

Table 1. Mean daily air temperature and rainfall range (Ingham, weather station 32078) during sampling.

\begin{tabular}{llrrr}
\hline Season & Study period & $\begin{array}{r}\text { Daily min } \\
\text { temperature }\left({ }^{\circ} \mathrm{C}\right)\end{array}$ & $\begin{array}{r}\text { Daily max } \\
\text { temperature }\left({ }^{\circ} \mathrm{C}\right)\end{array}$ & $\begin{array}{r}\text { Rainfall } \\
\left(\mathrm{mm} \mathrm{d}^{-1}\right)\end{array}$ \\
\hline Dry-cool & 17 June 2018 & $13.4-14.6$ & $27.7-28.2$ & 0 \\
Dry-hot & 23-29 October 2018 & $15.7-21.1$ & $32.2-36.2$ & 0 \\
Dry-cool & 31 May to 6 June 2019 & $10.9-17.5$ & $21.6-28.2$ & $0-25$ \\
Wet-hot & 17-22 February 2020 & $23.9-25.3$ & $33.6-34.5$ & $0-86$ \\
\hline
\end{tabular}

Soil texture analysis (\% sand, silt, clay) was performed with a simplified method for particle size determination (Kettler et al., 2001). Soil electrical conductivity (EC) and $\mathrm{pH}$ were measured using a conductivity meter (TPS WP-84, Australia) in soil-water slurry at $1: 5$. Soil subsamples were air-dried, sieved (2 mm), ground (Retsch ${ }^{\mathrm{TM}}$ mill), and analysed for the percentage of $\mathrm{N}(\% \mathrm{~N})$ and percentage of $\mathrm{C}(\% \mathrm{C})$ using an elemental analyser connected to a gas isotope ratio mass spectrometer (EA-Delta V Advantage IRMS, Griffith University). Additionally, soil samples from the top $10 \mathrm{~cm}$ were collected during each sampling to measure gravimetric soil moisture content and bulk density.

\subsection{Greenhouse gas fluxes}

We measured GHG fluxes $\left(\mathrm{CO}_{2}, \mathrm{CH}_{4}\right.$, and $\left.\mathrm{N}_{2} \mathrm{O}\right)$ at each site for 3 consecutive days during each sampling period except for the dry-cool period of 2018, when mangroves, salt marsh, and sugarcane were surveyed for $1 \mathrm{~d}$. The sampling was carried out between 09:00 and 11:00 LT, representing the mean daily temperatures, thus minimising variability in cumulative seasonal fluxes based on intermittent manual flux measurements (Reeves et al., 2016). Additionally, we assessed the variability in our measurements with tidal inundation in mangroves and salt marsh, which were regularly inundated $(\sim 10-30 \mathrm{~cm})$ during the hot-dry season. However, due to lo- 
gistic constraints, further sampling was conducted only during low tides.

We used static, manual gas chambers made of highdensity, round polyvinyl chloride pipe, which consisted of two units: a base $(r=12 \mathrm{~cm} ; h=18 \mathrm{~cm})$ and a detachable collar $(h=12 \mathrm{~cm}$; Hutchinson and Mosier, 1981; Kavehei et al., 2021). The chambers had lateral holes that could be left covered with rubber bungs at low water levels and left open at high water levels to allow water movement between sampling events. When the wetlands were inundated for the experiments, we used PVC extensions $(h=18 \mathrm{~cm})$. Five chambers were set $\sim 5 \mathrm{~cm}$ deep in the soil; separated 1 to $2 \mathrm{~m}$ from each other; and selectively located on soil with minimal vegetation, roots, and crab burrows. The chambers were set $1 \mathrm{~d}$ before sampling to minimise installation disturbance during the experiment (Rezaei Rashti et al., 2015). We were careful not to tramp around the chambers during installation and sampling. The fact that emissions were not significantly different among days $(p>0.05)$ provided us with confidence that disturbance due to installation was not problematic.

At the start of the experiment, gas chambers were closed. A sample was taken at time zero and then after $1 \mathrm{~h}$ with a $20 \mathrm{~mL}$ syringe and transferred to a $12 \mathrm{~mL}$ vacuumed container (Exetainer, Labco Ltd, High Wycombe, UK). During the dry-hot season, linearity tests of GHG fluxes with time were conducted by sampling at $0,20,40$, and $60 \mathrm{~min}$ at all chambers (Rezaei Rashti et al., 2016). For the rest of the experiments, linearity tests were performed in one chamber per site; $R^{2}$ values were consistently above 0.70 . During each experiment, soil temperature was measured next to each chamber. For each experiment, the base depth was recorded from five points within each chamber to calculate headspace volume. The obtained volumetric unit concentrations were converted to mass-based units using the ideal gas law (Hutchinson and Mosier, 1981).

The GHG concentrations of all samples were analysed within 2 weeks of sampling with a gas chromatograph (Shimadzu GC-2010 Plus). For $\mathrm{N}_{2} \mathrm{O}$ analysis, an electron capture detector was used with helium as the carrier gas, while $\mathrm{CH}_{4}$ was analysed on a flame ionisation detector with nitrogen as the carrier gas. For $\mathrm{CO}_{2}$ determination, the gas chromatograph was equipped with a thermal conductivity detector. Peak areas of the samples were compared against standard curves to determine concentrations (Chen et al., 2012). Seasonal cumulative GHG fluxes were calculated by modifying the equation described by Shaaban et al. (2015; Eq. 2):

seasonal cumulative GHG fluxes

$$
\begin{aligned}
& \left(\mathrm{mg} \mathrm{m}^{-2} \mathrm{yr}^{-1} \text { or } \mu \mathrm{g} \mathrm{m}^{-2} \mathrm{yr}^{-1}\right) \\
& =\sum_{i=1}^{n}(\mathrm{Ri} \times 24 \times \mathrm{Di} \times 17.38)
\end{aligned}
$$

where $\mathrm{Ri}$ is the gas emission rate $\left(\mathrm{mg} \mathrm{m}^{-2} \mathrm{~h}^{-1}\right.$ for $\mathrm{CO}_{2}$ and $\mu \mathrm{g} \mathrm{m}^{-2} \mathrm{~h}^{-1}$ for $\mathrm{CH}_{4}$ and $\mathrm{N}_{2} \mathrm{O}$ ); Di is the mean daily
GHG emission rate in a season $\left(\mathrm{mg} \mathrm{m}^{-2} \mathrm{~d}^{-1}\right.$ for $\mathrm{CO}_{2}$ and $\mu \mathrm{g} \mathrm{m}^{-2} \mathrm{~d}^{-1}$ for $\mathrm{CH}_{4}$ and $\mathrm{N}_{2} \mathrm{O}$ ) during low tide; and 17.38 is the number of weeks in each season, assuming these conditions were representative of the annual cycle (see Table 1).

Annual cumulative soil GHG fluxes $\left(\mathrm{CH}_{4}+\mathrm{N}_{2} \mathrm{O}\right)$ were calculated by integrating cumulative seasonal fluxes. These estimations did not account for soil $\mathrm{CO}_{2}$ values as our methodology with dark chambers only accounted for emissions from respiration and excluded uptake by primary productivity. The $\mathrm{CO}_{2 \text {-equivalent }}\left(\mathrm{CO}_{2 \text {-eq }}\right)$ values were estimated by multiplying $\mathrm{CH}_{4}$ and $\mathrm{N}_{2} \mathrm{O}$ emissions by 25 and 298, respectively (Solomon, 2007), which represented the radiative balance of these gases (Neubauer, 2021). For annual cumulative soil GHG flux calculations from coastal wetlands, we used GHG fluxes measured during low tide; therefore, our values did not incorporate the effect of tidal fluctuations. The spatial and temporal replication of this study targeted spatial variation within soil type ( $<50 \mathrm{~cm}$, five chambers), days ( $3 \mathrm{~d}$ per sampling), and seasons (three seasons per year). However, our replication within land use and wetland type was limited; thus, generalisations for all wetlands and land uses should be made acknowledging this limitation.

\subsection{Statistical analyses}

GHG flux data were tested for normality through Kolmogorov-Smirnov and Shapiro-Wilk tests. The data were then analysed for spatial and temporal differences with one-way analyses of variance (ANOVAs), where site and season were the predictive factors and the replicate (chamber) was the random factor of the model. When data were not normal, they were transformed $(\log 10$ or $1 / x)$ to comply with the assumptions of normality and homogeneity of variances. Some variables were not normally distributed despite transformations and were analysed with the nonparametric Kruskal-Wallis test and Mann-Whitney $U$ test. A Pearson correlation test was run to evaluate the correlation of GHGs with measured environmental factors. Analyses were performed with SPSS (v25, IBM, New York, USA), and values are presented as the mean \pm standard error (SE).

\section{Results}

\subsection{Soil physicochemical properties}

Soil physical and chemical parameters (mean values 0 $30 \mathrm{~cm}$ ) varied among sites (Table 2; see full results of statistical analyses in Sect. S5 in the Supplement). As expected, gravimetric moisture content was highest in the coastal wetlands and wet pasture $(>26 \%)$ and lowest in the sugarcane and the dry pasture $(<14 \%)$. All soils were acidic, especially the freshwater tidal forest and the wet pastures with values $<5$ throughout the sediment column; mangroves had the highest $\mathrm{pH}$ with $6.0 \pm 0.1$. The lowest $\mathrm{EC}$ was recorded in the pastures $\left(247 \pm 38\right.$ and $190 \pm 39 \mu \mathrm{Scm}^{-1}$ for the dry 
and wet pasture, respectively) and highest in the three natural coastal wetlands with $1418 \pm 104,8049 \pm 276$, and $8930 \pm$ $790 \mu \mathrm{S} \mathrm{cm}^{-1}$ for the freshwater tidal forest, salt marsh, and mangroves, respectively.

Soil bulk density was highest in sugarcane $(1.5 \pm$ $\left.0.1 \mathrm{~g} \mathrm{~cm}^{-3}\right)$ and lowest in the freshwater tidal forest $(0.6 \pm$ $0.1 \mathrm{~g} \mathrm{~cm}^{-3}$ ). For all sites, $\% \mathrm{C}$ was highest in the top $10 \mathrm{~cm}$ of the soil and decreased with depth, with the highest values in the freshwater tidal forest $(5.1 \pm 0.6 \%)$ and lowest in the salt marsh $(1.2 \pm 0.1 \%)$. Soil $\% \mathrm{~N}$ ranged from $0.1 \pm 0.0 \%$ to $0.4 \pm 0.1 \%$ in all sites, except in the freshwater tidal wetland, where it reached values of $0.6 \pm 0.0 \%$ in the top $10 \mathrm{~cm}$ (Table 2).

\subsection{Greenhouse gas fluxes}

Soil emissions for $\mathrm{CO}_{2}$ were significantly different among sites and times of the year $(t=155.09$ and $n=237$ with $p<0.001$; Fig. 2a). The highest $\mathrm{CO}_{2}$ emissions were measured during the wet-hot period in the dry pasture, where values reached $20308 \pm 1951 \mathrm{mg} \mathrm{m}^{-2} \mathrm{~d}^{-1}$, while the lowest values were measured in the salt marsh, the only site that acted as a sink of $\mathrm{CO}_{2}$ with an uptake rate of $-594 \pm$ $152 \mathrm{mg} \mathrm{m}^{-2} \mathrm{~d}^{-1}$. In the pastures, $\mathrm{CO}_{2}$ emissions were twice as high when dry, with cumulative annual emissions of $5748 \pm 303 \mathrm{~g} \mathrm{~m}^{-2} \mathrm{yr}^{-1}$, compared to when wet, with $2163 \pm$ $465 \mathrm{~g} \mathrm{~m}^{-2} \mathrm{yr}^{-1}$. For the coastal wetlands, cumulative annual $\mathrm{CO}_{2}$ emissions were highest in freshwater tidal forests with $2213 \pm 284 \mathrm{~g} \mathrm{~m}^{-2} \mathrm{yr}^{-1}$, followed by mangroves with $1493 \pm 111 \mathrm{~g} \mathrm{~m}^{-2} \mathrm{yr}^{-1}$, and lowest at the salt marsh with uptake rates of $-264 \pm 29 \mathrm{~g} \mathrm{~m}^{-2} \mathrm{yr}^{-1}$.

For $\mathrm{CH}_{4}$ fluxes, significant differences were observed among sites and seasons $(t=182.33$ and $n=237$ with $p<$ $0.001)$. The differences between different sites were substantial, with wet pasture having significantly higher $\mathrm{CH}_{4}$ emissions than any other site at rates $\sim 200$ times higher (Fig. 2b). For tidal coastal wetlands, emissions of $\mathrm{CH}_{4}$ were highest during the wet-hot season in all the sites except for the mangroves, which had similar emissions throughout the year (Fig. 2b). Overall, cumulative annual $\mathrm{CH}_{4}$ emissions were $209 \pm 36 \mathrm{~g} \mathrm{~m}^{-2} \mathrm{yr}^{-1}$ for the wet pasture followed by mangroves $\left(0.73 \pm 0.13 \mathrm{~g} \mathrm{~m}^{-2} \mathrm{yr}^{-1}\right)$, dry pasture $\left(0.15 \pm 0.03 \mathrm{~g} \mathrm{~m}^{-2} \mathrm{yr}^{-1}\right)$, freshwater tidal forest $(0.14 \pm$ $\left.0.03 \mathrm{~g} \mathrm{~m}^{-2} \mathrm{yr}^{-1}\right)$, salt marsh $\left(0.04 \pm 0.01 \mathrm{~g} \mathrm{~m}^{-2} \mathrm{yr}^{-1}\right)$, and sugarcane $\left(-0.04 \pm 0.02 \mathrm{~g} \mathrm{~m}^{-2} \mathrm{yr}^{-1}\right)$.

For $\mathrm{N}_{2} \mathrm{O}$ fluxes, the highest emissions (54.6 \pm $9.0 \mathrm{mg} \mathrm{m}^{-2} \mathrm{~d}^{-1}$ ) were from the dry pasture in the wethot season, followed by sugarcane $\left(20.5 \pm 2.7 \mathrm{mg} \mathrm{m}^{-2} \mathrm{~d}^{-1}\right)$ during the hot-dry period, which coincides with the post-fertilisation months (Fig. 2c). Overall, dry pastures had the highest cumulative annual $\mathrm{N}_{2} \mathrm{O}$ emissions $\left(7.99 \pm 2.26 \mathrm{~g} \mathrm{~m}^{-2} \mathrm{yr}^{-1}\right)$, followed by sugarcane $(2.37 \pm$ $\left.0.68 \mathrm{~g} \mathrm{~m}^{-2} \mathrm{yr}^{-1}\right)$, wet pasture $\left(1.32 \pm 0.33 \mathrm{mg} \mathrm{m}^{-2} \mathrm{~d}^{-1}\right)$, salt marsh $\left(0.33 \pm 0.11 \mathrm{mg} \mathrm{m}^{-2} \mathrm{~d}^{-1}\right)$, freshwater tidal forests $\left(0.04 \pm 0.0 \mathrm{~g} \mathrm{~m}^{-2} \mathrm{yr}^{-1}\right)$, and finally mangroves $\left(0.02 \pm 0.04 \mathrm{~g} \mathrm{~m}^{-2} \mathrm{yr}^{-1}\right)$. However, these differences were only significant when considering the interaction between the time of the year and site $(t=100.21$ and $n=237$ with $p<0.001)$.

The $\mathrm{CH}_{4}$ fluxes did not vary significantly between the low and high tide within all coastal wetlands. Contrarily, for salt marsh, $\mathrm{CO}_{2}$ was taken during the high tide $(-1.12 \pm$ $\left.0.24 \mathrm{~g} \mathrm{~m}^{-2} \mathrm{~d}^{-1}\right)$ but emitted $\left(0.69 \pm 0.4 \mathrm{~g} \mathrm{~m}^{-2} \mathrm{~d}^{-1}\right)$ during the low tide $\left(F_{1,28}=20.06\right.$ with $\left.p<0.001\right)$. Finally, for $\mathrm{N}_{2} \mathrm{O}$, fluxes differed in all coastal wetlands, with higher uptakes in the high tide for mangroves $\left(F_{1,28}=38.28\right.$ with $p<0.001 ; F_{1,28}=13.53$ with $\left.p=0.001\right)$ and higher emissions in salt marsh $\left(F_{1,28}=38.31\right.$ with $\left.p<0.001\right)$ during low tide (Sect. S3). These results suggested that there was a likely variability for $\mathrm{CO}_{2}$ and $\mathrm{N}_{2} \mathrm{O}$ fluxes, depending on the time of sampling.

The wet pasture had the highest total cumulative soil GHG emissions $\left(\mathrm{CH}_{4}+\mathrm{N}_{2} \mathrm{O}\right)$ with $56124 \mathrm{CO}_{2 \text {-eq }} \mathrm{kg} \mathrm{ha}^{-1} \mathrm{yr}^{-1}$ followed by dry pasture at $23890 \mathrm{CO}_{2-\mathrm{eq}} \mathrm{kgha}^{-1} \mathrm{yr}^{-1}$ and sugarcane at $7142 \mathrm{CO}_{2 \text {-eq }} \mathrm{kg} \mathrm{ha}^{-1} \mathrm{yr}^{-1}$, while coastal wetlands had comparatively lower cumulative soil GHG emissions with 884,235 , and $144 \mathrm{CO}_{2 \text {-eq }} \mathrm{kgha}^{-1} \mathrm{yr}^{-1}$ for salt marsh, mangroves, and freshwater tidal forests, respectively. Overall, the three coastal wetlands measured in this study had lower total cumulative GHG emissions at $1263 \mathrm{CO}_{2-\mathrm{eq}} \mathrm{kg} \mathrm{ha}^{-1} \mathrm{yr}^{-1}$ compared to the alternate agricultural land uses, which emitted $87156 \mathrm{CO}_{2 \text {-eq }} \mathrm{kg} \mathrm{ha}^{-1} \mathrm{yr}^{-1}$.

\subsection{Greenhouse gas emissions and environmental factors}

Overall, we found that not one single parameter measured in this study could explain GHG fluxes for all sites except land use. The $\mathrm{CO}_{2}$ emissions were not significantly correlated with bulk density $\left(R^{2}=0.026 ; p=0.918 ; n=\right.$ $18)$, percent WFPS (\% WFPS $)\left(R^{2}=-0.003 ; p=0.99 ; n=\right.$ $18)$, or soil temperature $\left(R^{2}=0.296 ; p=0.233 ; n=18\right)$. Soil $\mathrm{CH}_{4}$ emissions were not correlated with bulk density $\left(R^{2}=-0.096 ; p=0.706 ; n=18\right)$, \% WFPS $\left(R^{2}=0.224\right.$; $p=0.372 ; n=18)$, or soil temperature $\left(R^{2}=0.286 ; p=\right.$ $0.25 ; n=18)$. Finally, no correlation was found between $\mathrm{N}_{2} \mathrm{O}$ emissions and bulk density $\left(R^{2}=-0.349 ; p=0.156\right.$; $n=18)$, \% WFPS $\left(R^{2}=-0.34 ; p=0.168 ; n=18\right)$, or soil temperature $\left(R^{2}=-0.241 ; p=0.335 ; n=18\right)$. The full raw dataset of GHG fluxes is provided in Sect. S1.

\section{Discussion}

The soils of the three coastal wetlands measured in this study (mangroves, salt marshes, and freshwater tidal forests) had significantly lower GHG emissions than those from two alternative land uses common in tropical Australia (sugarcane and grazing pastures). Notably, we found that coastal wetlands had 200-times-lower $\mathrm{CH}_{4}$ emissions and 7-times-lower $\mathrm{N}_{2} \mathrm{O}$ 
Table 2. Physicochemical characteristics for the soil of natural coastal wetlands, sugarcane, and pastures (dry and ponded) for the top $30 \mathrm{~cm}$ of soil in tropical Australia. $\mathrm{C}$ is carbon; $\mathrm{N}$ is nitrogen; EC is electrical conductivity. Values are the mean \pm standard error $(n=5)$.

\begin{tabular}{|c|c|c|c|c|c|c|c|c|}
\hline \multicolumn{2}{|l|}{ Site } & $\begin{array}{l}\text { Depth } \\
(\mathrm{cm})\end{array}$ & $\begin{array}{r}\text { Gravimetric } \\
\text { moisture } \\
\text { content }(\%)\end{array}$ & $\mathrm{pH}$ & $\begin{array}{r}\mathrm{EC} \\
\left(\mu \mathrm{cm}^{-1}\right)\end{array}$ & $\begin{array}{r}\text { Bulk } \\
\text { density } \\
\left(\mathrm{g} \mathrm{cm}^{-3}\right)\end{array}$ & $\% \mathrm{C}$ & $\% \mathrm{~N}$ \\
\hline \multirow{4}{*}{\multicolumn{2}{|c|}{ Mangroves }} & $0-10$ & $41.7 \pm 1.1$ & $5.9 \pm 0.1$ & $12550 \pm 524$ & $1.14 \pm 0.05$ & $2.3 \pm 0.1$ & $0.18 \pm 0.01$ \\
\hline & & $10-20$ & $34.6 \pm 0.7$ & $5.9 \pm 0.3$ & $12164 \pm 5560$ & $1.34 \pm 0.03$ & $1.7 \pm 0.2$ & $0.12 \pm 0.01$ \\
\hline & & $20-30$ & $31.3 \pm 0.6$ & $6.2 \pm 0.1$ & $5560 \pm 365$ & $1.95 \pm 0.12$ & $0.9 \pm 0.1$ & $0.07 \pm 0.01$ \\
\hline & & Mean & $35.9 \pm 1.2$ & $6.0 \pm 0.1$ & $8930 \pm 790$ & $1.48 \pm 0.10$ & $1.6 \pm 0.2$ & $0.12 \pm 0.01$ \\
\hline \multirow{4}{*}{\multicolumn{2}{|c|}{ Salt marsh }} & $0-10$ & $25.6 \pm 1.2$ & $5.8 \pm 0.2$ & $8442 \pm 435$ & $1.12 \pm 0.04$ & $1.4 \pm 0.1$ & $0.11 \pm 0.01$ \\
\hline & & $10-20$ & $26.6 \pm 0.3$ & $5.8 \pm 0.1$ & $8666 \pm 437$ & $1.47 \pm 0.05$ & $1.3 \pm 0.1$ & $0.12 \pm 0.01$ \\
\hline & & $20-30$ & $26.4 \pm 0.2$ & $5.9 \pm 0.3$ & $7040 \pm 316$ & $1.56 \pm 0.03$ & $1.0 \pm 0.3$ & $0.10 \pm 0.02$ \\
\hline & & Mean & $26.2 \pm 0.4$ & $5.8 \pm 0.1$ & $8049 \pm 276$ & $1.38 \pm 0.06$ & $1.2 \pm 0.1$ & $0.11 \pm 0.01$ \\
\hline \multirow{4}{*}{\multicolumn{2}{|c|}{ Freshwater tidal forest }} & $0-10$ & $33.4 \pm 0.5$ & $4.4 \pm 0.2$ & $1099 \pm 17$ & $0.46 \pm 0.05$ & $7.8 \pm 0.1$ & $0.62 \pm 0.03$ \\
\hline & & $10-20$ & $24.9 \pm 0.6$ & $4.2 \pm 0.0$ & $1272 \pm 164$ & $0.71 \pm 0.02$ & $5.4 \pm 0.0$ & $0.46 \pm 0.04$ \\
\hline & & $20-30$ & $22.4 \pm 0.7$ & $4.2 \pm 0.1$ & $1882 \pm 47$ & $0.83 \pm 0.03$ & $2.2 \pm 0.1$ & $0.10 \pm 0.00$ \\
\hline & & Mean & $26.9 \pm 1.3$ & $4.3 \pm 0.1$ & $1418 \pm 104$ & $0.59 \pm 0.05$ & $5.1 \pm 0.6$ & $0.39 \pm 0.06$ \\
\hline \multirow{4}{*}{\multicolumn{2}{|c|}{ Sugarcane }} & $0-10$ & $9.1 \pm 0.4$ & $5.7 \pm 0.1$ & $429 \pm 12$ & $1.35 \pm 0.08$ & $1.5 \pm 0.1$ & $0.10 \pm 0.00$ \\
\hline & & $10-20$ & $12.1 \pm 0.6$ & $5.3 \pm 0.3$ & $365 \pm 11$ & $1.46 \pm 0.06$ & $1.5 \pm 0.1$ & $0.12 \pm 0.01$ \\
\hline & & $20-30$ & $13.7 \pm 0.2$ & $4.7 \pm 0.2$ & $351 \pm 2$ & $1.64 \pm 0.10$ & $1.3 \pm 0.1$ & $0.10 \pm 0.00$ \\
\hline & & Mean & $11.7 \pm 0.6$ & $5.2 \pm 0.2$ & $382 \pm 11$ & $1.48 \pm 0.05$ & $1.4 \pm 0.1$ & $0.11 \pm 0.00$ \\
\hline \multirow[t]{8}{*}{ Pasture } & Dry & $0-10$ & $12.4 \pm 0.3$ & $4.1 \pm 0.0$ & $378 \pm 21$ & $0.78 \pm 0.06$ & $3.1 \pm 0.3$ & $0.26 \pm 0.03$ \\
\hline & & $10-20$ & $13.6 \pm 0.1$ & $4.4 \pm 0.1$ & $279 \pm 60$ & $1.21 \pm 0.14$ & $1.6 \pm 0.4$ & $0.12 \pm 0.04$ \\
\hline & & $20-30$ & $14.5 \pm 0.7$ & $4.4 \pm 0.3$ & $84 \pm 4$ & $1.32 \pm 0.19$ & $1.6 \pm 0.2$ & $0.12 \pm 0.02$ \\
\hline & & Mean & $13.5 \pm 0.3$ & $4.3 \pm 0.1$ & $247 \pm 38$ & $1.10 \pm 0.10$ & $2.1 \pm 0.3$ & $0.17 \pm 0.02$ \\
\hline & Wet & $0-10$ & $52.1 \pm 0.4$ & $4.8 \pm 0.0$ & $358 \pm 71$ & $0.62 \pm 0.06$ & $3.6 \pm 0.3$ & $0.29 \pm 0.02$ \\
\hline & & $10-20$ & $47.7 \pm 0.4$ & $4.9 \pm 0.1$ & $117 \pm 11$ & $1.30 \pm 0.02$ & $1.7 \pm 0.1$ & $0.10 \pm 0.01$ \\
\hline & & $20-30$ & $46.4 \pm 0.2$ & $5.1 \pm 0.1$ & $95 \pm 6$ & $1.31 \pm 0.02$ & $1.5 \pm 0.1$ & $0.10 \pm 0.00$ \\
\hline & & Mean & $48.7 \pm 0.7$ & $4.9 \pm 0.0$ & $190 \pm 39$ & $1.07 \pm 0.09$ & $2.3 \pm 0.3$ & $0.16 \pm 0.03$ \\
\hline
\end{tabular}

compared to wet pastures and sugarcane soils, respectively. These results support our hypothesis that the management or conversion of unused sugarcane land and ponded pastures in tropical Australia could be restored to coastal wetlands and result in significant GHG mitigation.

The variability in GHG fluxes was best explained by land use and wetland type; however, some trends with seasons were evident. For instance, $\mathrm{CO}_{2}$ and $\mathrm{N}_{2} \mathrm{O}$ emissions were lowest during the dry-cool periods. Reduced emissions at low temperatures are expected as the temperature is a primary driver of any metabolic process, including respiration and nitrification-denitrification. Mangroves tend to have higher $\mathrm{CO}_{2}$ emissions as temperature increases (Liu and Lai, 2019), and forests have significantly higher $\mathrm{N}_{2} \mathrm{O}$ emissions during warm seasons (Schindlbacher et al., 2004). Emissions of $\mathrm{CH}_{4}$ also tend to increase with temperature as the activity of methane-producing soil microbes (Ding et al., 2004) and the availability of carbon are higher in warmer conditions (Yvon-Durocher et al., 2011). However, most studies to date on GHG fluxes have been conducted in temperate locations, where temperature differences throughout the year are smaller than in tropical regions. For tropical regions, increased GHG emissions are likely to be strongly affected by the "Birch effect", which refers to a short-term but substantial increase in respiration from soils under the effect of precipitation during the early wet season (Fernandez-Bou et al., 2020).

The main factor associated with GHG fluxes was land use and type of wetland. Notably, coastal wetlands, even the freshwater tidal forests, had much lower emissions than wet pastures. This significant difference could be attributed to terminal electron acceptors in the soils (e.g. iron, sulfate, manganese) of the coastal wetlands, which could inhibit methanogenesis (Kögel-Knabner et al., 2010; Sahrawat, 2004). Sulfate-reducing bacteria are also likely to outcompete methane-producing bacteria (methanogens) in the presence of high sulfate concentrations in tidal wetlands, resulting in low $\mathrm{CH}_{4}$ production. Competition between methanogens and methanotrophs may result in a net balance of low $\mathrm{CH}_{4}$ production despite freshwater conditions (Maietta et al., 2020). Additionally, microorganisms living within the bark of Melaleuca trees can consume $\mathrm{CH}_{4}$ (Jeffrey et al., 

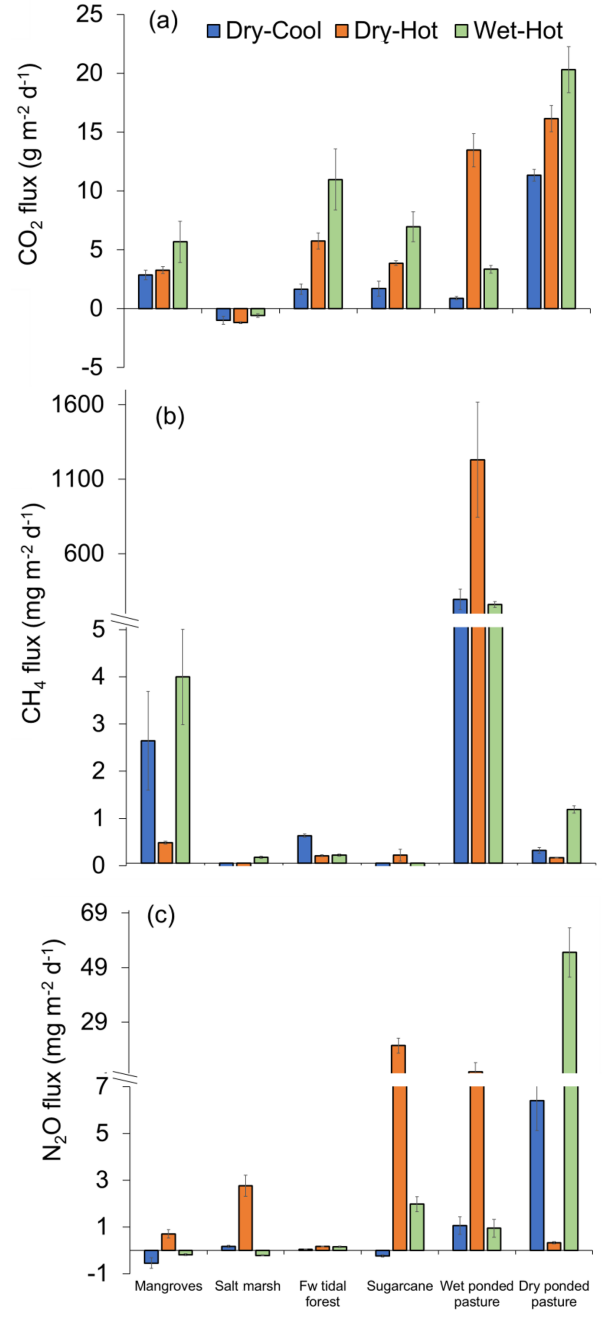

Figure 2. Greenhouse gas fluxes $\left(\mathrm{mg} \mathrm{m}^{-2} \mathrm{~d}^{-1}\right)$ of (a) $\mathrm{CO}_{2}$, (b) $\mathrm{CH}_{4}$, and (c) $\mathrm{N}_{2} \mathrm{O}$ from the soils of tropical coastal wetlands - mangroves, salt marsh, freshwater (Fw) tidal forest - and two alternative land uses - sugarcane and pastures (wet and dry) - during three periods of the year: dry-cool, dry-hot, and wet-hot.

2021), so it is possible that similar bacteria could reduce $\mathrm{CH}_{4}$ emissions in the soil. Interestingly, variability within $\mathrm{CH}_{4}$ fluxes among sites was very high, despite being very close to each other (Fig. 1b). These differences highlight the importance of land use in GHG fluxes, which are likely to significantly alter the microbial community composition and abundance, changing rapidly over small spatial scales (Drenovsky et al., 2010; Martiny et al., 2006).

Our results are consistent with other studies, showing the importance of land use in GHG emissions. For instance, in a Mediterranean climate, the drained agricultural land use types, pasture and corn, were larger $\mathrm{CO}_{2}$ emitters than restored wetlands (Knox et al., 2015). Clearing of wetlands for agricultural development, such as the drainage of peatlands, results in very high $\mathrm{CO}_{2}$ emissions (Hirano et al., 2012;
Nieveen et al., 2005; Veenendaal et al., 2007), and restoration of these wetlands could decrease these emissions (Cameron et al., 2021). Additionally, some of the wetland types, such as marshes, were occasional sinks of $\mathrm{CO}_{2}$ and $\mathrm{CH}_{4}$, consistent with previous studies where intertidal wetlands are a sink of GHGs at least under some conditions or during some times of the year (Knox et al., 2015; Maher et al., 2016).

The fluxes measured in the coastal wetlands of this study, -1191 to $10970 \mathrm{mg} \mathrm{m}^{-2} \mathrm{~d}^{-1}$ for $\mathrm{CO}_{2},-0.3$ to $3.9 \mathrm{mg} \mathrm{m}^{-2} \mathrm{~d}^{-1}$ for $\mathrm{CH}_{4}$, and -0.2 to $2.8 \mathrm{mg} \mathrm{m}^{-2} \mathrm{~d}^{-1}$ for $\mathrm{N}_{2} \mathrm{O}$, were within the range of those measured in other subtropical/tropical wetlands worldwide (except for the negative $\mathrm{CO}_{2}$ fluxes in salt marsh soils, Table 3). Fluxes can range from 44 to $11328 \mathrm{mg} \mathrm{m}^{-2} \mathrm{~d}^{-1}$ for $\mathrm{CO}_{2}$, from 0.03 to $1255 \mathrm{mg} \mathrm{m}^{-2} \mathrm{~d}^{-1}$ for $\mathrm{CH}_{4}$, and from 0.1 to $279 \mathrm{mg} \mathrm{m}^{-2} \mathrm{~d}^{-1}$ for $\mathrm{N}_{2} \mathrm{O}$ (Table 3). Despite being in tropical regions, GHG fluxes from this study were lower compared to other climates (Table 3). Contrary to previous studies, $\mathrm{CO}_{2}$ uptake by salt marsh soil was likely to be linked with dark $\mathrm{CO}_{2}$ fixation in wetland soils (Akinyede et al., 2020; Mar Lynn et al., 2017). Wetland soils exhibit autotrophic bacteria which contribute to dark $\mathrm{CO}_{2}$ fixation at $\sim 311 \mathrm{mg} \mathrm{m}^{-2} \mathrm{~d}^{-1}$; however these rates could vary depending upon abundance and diversity of microbial communities (Akinyede et al., 2020). Further studies exploring the presence and abundance of $\mathrm{CO}_{2}$-fixing bacteria in salt marsh soils are recommended. The general lower nitrogen pollution in Australia's soils and waterways compared to other countries may partially explain the lower emissions. However, the GHG flux measurements from this study did not account for the effects of vegetation, which can alter fluxes. For instance, some plant species of rice paddies (Timilsina et al., 2020) and Miscanthus sinensis (Lenhart et al., 2019) can increase $\mathrm{N}_{2} \mathrm{O}$ emissions, and some tree species can facilitate $\mathrm{CH}_{4}$ efflux from the soil (Pangala et al., 2013). Finally, changes in emissions between low and high tides were detected for $\mathrm{CO}_{2}$ and $\mathrm{N}_{2} \mathrm{O}$. Thus, future studies that include vegetation and changes within tidal cycles will improve GHG flux estimates for coastal wetlands.

\subsection{Management implications}

Under the Paris Agreement, Australia has committed to reducing GHG emissions to $26 \%-28 \%$ below its $2005 \mathrm{lev}$ els by 2030 . With annual emissions of $153 \times 10^{6} \mathrm{t}$ of carbon dioxide equivalent ( $\left.\mathrm{MtCO}_{2 \text {-eq }} \mathrm{yr}^{-1}\right)$, Queensland is a major GHG emitter in Australia ( 28.7\% of the total in 2016; Department of Environment and Science, Queensland, 2016).

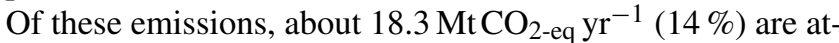
tributed to agriculture, while land use change and forestry emit $12.1 \mathrm{MtCO}_{2 \text {-eq }} \mathrm{yr}^{-1}$ (DES, 2016). Production of $\mathrm{CH}_{4}$ from ruminant animals, primarily cattle, contribute $82 \%$ of agriculture-related emissions (DES, 2016). Therefore, any GHG mitigation strategy involving land use change could be important for Australia to achieve its national goals. 
Table 3. Comparison of GHG fluxes $\left(\mathrm{mg} \mathrm{m}^{-2} \mathrm{~d}^{-1}\right)$ with other studies.

\begin{tabular}{|c|c|c|c|c|c|c|}
\hline Reference & Climate & Country & Ecosystem & $\mathrm{CO}_{2}$ fluxes & $\mathrm{CH}_{4}$ fluxes & $\mathrm{N}_{2} \mathrm{O}$ fluxes \\
\hline Allen et al. (2011) & Subtropical & Australia & Mangrove estuary & - & 1.5 to 51 & - \\
\hline Cabezas et al. (2018) & Subtropical & USA & Mangrove estuary & - & 0.3 to 2.2 & - \\
\hline Li and Mitsch (2016) & Subtropical & USA & $\begin{array}{l}\text { Flooded brackish } \\
\text { marsh }\end{array}$ & - & $212 \pm 51$ & - \\
\hline Morse and Marcelo Ardón (2012) & Subtropical & USA & Forested wetlands & 7224 to 11328 & 118 to 1255 & 46 to 279 \\
\hline Musenze et al. (2014) & Subtropical & Australia & Mangrove estuary & - & 5 to 448 & 0.1 to 3.4 \\
\hline Whiting and Chanton (2001) & Subtropical & USA & Typha marsh & 409 to 477 & 189 to 264 & - \\
\hline Mitsch et al. (2013) & Tropical & South Africa & $\begin{array}{l}\text { Seasonally flooded } \\
\text { wetland }\end{array}$ & - & $264 \pm 29$ & - \\
\hline Krithika et al. (2008) & Tropical & India & Mangroves & - & 25 to 50 & - \\
\hline Kristensen et al. (2008) & Tropical & Tanzania & Mangroves & 44 to 3521 & 1.9 to 6.5 & - \\
\hline Biswas et al. (2007) & Tropical & India & Mangrove estuary & - & 0.03 to 2.16 & - \\
\hline Purvaja et al. (2004) & Tropical & India & Mangrove estuary & - & 10 to 85 & - \\
\hline Kreuzwieser et al. (2003) & Tropical & Australia & Mangroves & - & 0.6 to 11 & - \\
\hline Kiese and Butterbach-Bahl (2002) & Tropical & Australia & Tropical rainforest & 2208 to 3288 & & 1.9 to 3.2 \\
\hline Purvaja and Ramesh (2000) & Tropical & India & Mangroves & - & 63 to 434 & - \\
\hline Sotomayor et al. (1994) & Tropical & Puerto Rico & Mangroves & - & 5 to 110 & - \\
\hline Barnes et al. (2006) & Tropical & India & Mangroves & - & 9 to 15 & - \\
\hline Melling et al. (2012) & Tropical & Malaysia & Peat swamp forest & 3384 & 21 to 29 & \\
\hline This study & Tropical & Australia & $\begin{array}{l}\text { Freshwater tidal } \\
\text { forest }\end{array}$ & 1640 to 10970 & 0.16 to 0.59 & -0.19 to 0.7 \\
\hline This study & Tropical & Australia & Salt marshes & -594 to -1191 & -0.25 to 0.12 & -0.22 to 2.76 \\
\hline This study & Tropical & Australia & Mangroves & 2852 to 5669 & 0.44 to 3.95 & 0.04 to 0.16 \\
\hline Oertel et al. (2016) & (Sub)tropical & Global & Wetlands & - & -1.08 to 1169 & - \\
\hline Oertel et al. (2016) & Temperate & Global & Wetlands & - & -1.49 to 1510 & - \\
\hline Oertel et al. (2016) & Mediterranean & Global & Wetlands & - & - & -2.6 to 9.4 \\
\hline Al-Haj and Fulweiler (2020) & - & Global & Mangroves & - & -1.1 to 1169 & -0.2 to 6.3 \\
\hline Al-Haj and Fulweiler (2020) & - & Global & Salt marshes & 6844 to 34983 & 0.38 to 3002 & -7.39 to 28.52 \\
\hline Rosentreter et al. (2021) & - & Global & Mangroves & 4563 to 30800 & -0.69 to 10.78 & -1.69 to 4.65 \\
\hline Rosentreter et al. (2021) & - & Global & Salt marshes & 3802 to 20914 & 107 to 168 & 4.96 \\
\hline IPCC (2013) & Tropical & Global & Swamp forests & & 30.76 to 2149 & \\
\hline
\end{tabular}

Note that a dash means no data were available; GHG fluxes as $\mathrm{CO}_{2}-\mathrm{C}, \mathrm{CH}_{4}-\mathrm{C}$, and $\mathrm{N}_{2} \mathrm{O}-\mathrm{N}$ were multiplied by $3.66,1.34$, and 1.57 , respectively, to calculate $\mathrm{CO}_{2}$, $\mathrm{CH}_{4}$, and $\mathrm{N}_{2} \mathrm{O}$ fluxes (National Greenhouse Accounts Factors, Australian Government Department of Industry, Science, Energy and Resources, 2020).

This study supports the application of three management actions that could reduce GHG emissions. First, the conversion of ponded pastures to coastal wetlands is likely to reduce soil GHG emissions. Our results showed that wet pastures emit $56 \mathrm{tCO}_{2 \text {-eq }} \mathrm{ha}^{-1} \mathrm{yr}^{-1}$ of the total GHG emissions $\left(\mathrm{CH}_{4}+\mathrm{N}_{2} \mathrm{O}\right)$ compared with $0.2 \mathrm{tCO}_{2 \text {-eq }} \mathrm{ha}^{-1} \mathrm{yr}^{-1}$, $0.1 \mathrm{tCO}_{2 \text {-eq }} \mathrm{ha}^{-1} \mathrm{yr}^{-1}$, and $0.9 \mathrm{tCO}_{2 \text {-eq }} \mathrm{ha}^{-1} \mathrm{yr}^{-1}$ from mangroves, freshwater tidal forest, and salt marshes, respectively. This implies that about $55 \mathrm{tCO}_{2-\mathrm{eq}} \mathrm{ha}^{-1} \mathrm{yr}^{-1}$ of emissions from the soils could be potentially avoided by converting wet pastures to coastal wetlands. The carbon mitigation for GHG emissions only from soil could provide $\sim$ AUD $894 \mathrm{ha}^{-1} \mathrm{yr}^{-1}$, assuming a carbon value of AUD 15.99 per tonne of $\mathrm{CO}_{2 \text {-eq }}$ (Australian Government Clean Energy Regulator, 2021). This mitigation could be added to the carbon sequestration through sediment accumulation and tree growth that results from wetland restoration. Legal enablers in Queensland are in place to manage unproductive agricultural land this way (Bell-James and Lovelock, 2019) and could provide an alternative income source for farmers.
A second management option would be to reduce the time pastures are kept underwater. Dry pastures produced significantly less $\mathrm{CH}_{4}$ with $\sim 0.005 \mathrm{~kg} \mathrm{ha}^{-1} \mathrm{~d}^{-1}$ than wet pastures with $6 \mathrm{~kg} \mathrm{ha}^{-1} \mathrm{~d}^{-1}$. For comparison, an average cow produces $141 \mathrm{~g} \mathrm{CH}_{4} \mathrm{~d}^{-1}$ (McGinn et al., 2011), and our study farm supported around 900 cattle over 250 ha throughout the year, equivalent to $185 \mathrm{~kg} \mathrm{ha}^{-1} \mathrm{yr}^{-1}$ compared to $2 \mathrm{~kg} \mathrm{ha}^{-1} \mathrm{yr}^{-1}$ and $2090 \mathrm{kgha}^{-1} \mathrm{yr}^{-1}$ of $\mathrm{CH}_{4}$ from dry and wet pasture, respectively. This implies that nearly $92 \%$ of the $\mathrm{CH}_{4}$ emissions came from wet pastures, while dry pasture and grazing cattle had a low share in total $\mathrm{CH}_{4}$ emissions in this case scenario. Therefore, land use management of wet pastures may be an opportunity to reduce agriculture-related $\mathrm{CH}_{4}$ emissions. Future studies should increase the number of sites of ponded pastures to account for variability in hydrology, fertilisation, and on-farm cattle density. However, the exceptionally large difference (2-3 orders of magnitude) between dry and ponded pastures and other coastal wetlands provides confidence that pasture management could provide significant GHG mitigation. 
Finally, fertiliser management in sugarcane could reduce $\mathrm{N}_{2} \mathrm{O}$ emissions. Higher $\mathrm{N}_{2} \mathrm{O}$ emissions of $17.6 \mathrm{mg} \mathrm{m}^{-2} \mathrm{~d}^{-1}$ were measured in the sugarcane crop following fertilisation during the dry-hot season. Comparatively, natural wetlands had low $\mathrm{N}_{2} \mathrm{O}$ emissions ( 0.16 to $2.79 \mathrm{mg} \mathrm{m}^{-2} \mathrm{~d}^{-1}$ ), and even the salt marsh was an occasional sink. Thus, improved management of fertiliser applications could result in GHG emission mitigation. Some activities include the split application of nitrogen fertiliser in combination with low irrigation, reduction in fertiliser application rates, the substitution of nitrate-based fertiliser for urea (Rezaei Rashti et al., 2015), removing the mulch layer before fertiliser application (Pinheiro et al., 2019; Xu et al., 2019; Zaehle and Dalmonech, 2011), or the conversion of unproductive sugarcane to coastal wetlands.

\section{Conclusions}

The GHG emissions from three coastal wetlands in tropical Australia (mangroves, salt marsh, and freshwater tidal forests) were consistently lower than those from two common agricultural land uses of the region (sugarcane and pastures) across three climatic conditions (dry-cool, dry-hot, and wet-hot). Ponded pastures emitted 200 times more $\mathrm{CH}_{4}$ and sugarcane emitted 7 times more $\mathrm{N}_{2} \mathrm{O}$ than any natural coastal wetland measured. If these high emissions are persistent in other locations and within other tropical regions, conversion of pastures and sugarcane to similar coastal wetlands could provide significant GHG mitigation. As nations try to reach their emission reduction targets, projects aimed at converting or restoring coastal wetlands can financially benefit farmers while providing additional co-benefits.

Data availability. All data are provided in the Supplement.

Supplement. The supplement related to this article is available online at: https://doi.org/10.5194/bg-18-5085-2021-supplement.

Author contributions. NI and MFA designed the project. NI, BSF, and EK carried out experiments. NI, EK, and MFA analysed the data. NI and MFA prepared the manuscript with contributions from DTM, SEB, and MRR.

Competing interests. The authors declare that they have no conflict of interest.

Disclaimer. Publisher's note: Copernicus Publications remains neutral with regard to jurisdictional claims in published maps and institutional affiliations.
Acknowledgements. We acknowledge the traditional owners of the land in which the field study was conducted, especially the Nywaigi people from Mungalla Station. We are also thankful to Sam and Santo Lamari for allowing us to work on their property and for sharing their local knowledge. We are thankful to Charles Cadier and Julieta Gamboa for their contribution to the fieldwork. We are very thankful to the anonymous referees for their valuable feedback, which helped to improve the quality of the article.

Financial support. This research has been supported by the QLD Government (Industry Research Fellowship - Advance Queensland).

Review statement. This paper was edited by Sara Vicca and reviewed by two anonymous referees.

\section{References}

Al-Haj, A. N. and Fulweiler, R. W.: A synthesis of methane emissions from shallow vegetated coastal ecosystems, Glob. Change Biol., 26, 2988-3005, https://doi.org/10.1111/gcb.15046, 2020.

Akinyede, R., Taubert, M., Schrumpf, M., Trumbore, S., and Küsel, $\mathrm{K}$.: Rates of dark $\mathrm{CO}_{2}$ fixation are driven by microbial biomass in a temperate forest soil, Soil Biol. Biochem., 150, 107950 , https://doi.org/10.1016/J.SOILBIO.2020.107950, 2020.

Allen, D., Dalal, R. C., Rennenberg, H., and Schmidt, S.: Seasonal variation in nitrous oxide and methane emissions from subtropical estuary and coastal mangrove sediments, Australia, Plant Biol., 13, 126-133, https://doi.org/10.1111/j.14388677.2010.00331.x, 2011.

Angle, J. C., Morin, T. H., Solden, L. M., Narrowe, A. B., Smith, G. J., Borton, M. A., Rey-Sanchez, C., Daly, R. A., Mirfenderesgi, G., Hoyt, D. W., Riley, W. J., Miller, C. S., Bohrer, G., and Wrighton, K. C.: Methanogenesis in oxygenated soils is a substantial fraction of wetland methane emissions, Nat. Commun., 8, 1567, https://doi.org/10.1038/s41467-017-01753-4, 2017.

Australian Bureau of Meteorology, ABM: Monthly Climate Statistics for "LUCINDA POINT" [032141], available at: http://www. bom.gov.au/jsp/ncc/cdio/cvg/av (last access: 5 May 2021), 2020.

Australian Government Clean Energy Regulator: Quarterly Carbon Market report, March 2021, available at: http://www.cleanenergyregulator.gov.au/DocumentAssets/ Documents/Quarterly\%20Carbon\%20Market\%20Report\% 20-\%20March\%20Quarter\%202021.pdf, last access: 11 August 2021.

Baldock, J. A., Wheeler, I., McKenzie, N., and McBrateny, A.:, Crop Pasture Sci., 63, 269-283, https://doi.org/10.1071/CP11170, 2012.

Barnes, J., Ramesh, R., Purvaja, R., Rajkumar, A. N., Kumar, B. S., Krithika, K., Ravichandran, K., Uher, G., and Upstill-Goddard, R.: Tidal dynamics and rainfall control $\mathrm{N}_{2} \mathrm{O}$ and $\mathrm{CH}_{4}$ emissions from a pristine mangrove creek, Geophys. Res. Lett., 33, L15405, https://doi.org/10.1029/2006GL026829, 2006.

Bauza, J. F., Morell, J. M., and Corredor, J. E.: Biogeochemistry of nitrous oxide production in the red mangrove (Rhizophora 
mangle) forest sediments, Estuar. Coast. Shelf S., 55, 697-704, https://doi.org/10.1006/ecss.2001.0913, 2002.

Bell-James, J. and Lovelock, C. E.: Legal barriers and enablers for reintroducing tides: An Australian case study in reconverting ponded pasture for climate change mitigation, Land use policy, 88, 104192, https://doi.org/10.1016/J.LANDUSEPOL.2019.104192, 2019.

Biswas, H., Mukhopadhyay, S. K., Sen, S., and Jana, T. K.: Spatial and temporal patterns of methane dynamics in the tropical mangrove dominated estuary, NE coast of Bay of Bengal, India, J. Marine Syst., 68, 55-64, https://doi.org/10.1016/j.jmarsys.2006.11.001, 2007.

Cabezas, A., Mitsch, W. J., MacDonnell, C., Zhang, L., Bydałek, F., and Lasso, A.: Methane emissions from mangrove soils in hydrologically disturbed and reference mangrove tidal creeks in southwest Florida, Ecol. Eng., 114, 57-65, https://doi.org/10.1016/j.ecoleng.2017.08.041, 2018.

Cameron, C., Hutley, L. B., Munksgaard, N. C., Phan, S., Aung, T., Thinn, T., Aye, W. M., and Lovelock, C. E.: Impact of an extreme monsoon on $\mathrm{CO}_{2}$ and $\mathrm{CH}_{4}$ fluxes from mangrove soils of the Ayeyarwady Delta, Myanmar, Sci. Total Environ., 760, 143422, https://doi.org/10.1016/J.SCITOTENV.2020.143422, 2021.

Chen, G. C., Tam, N. F. Y., and Ye, Y.: Spatial and seasonal variations of atmospheric $\mathrm{N}_{2} \mathrm{O}$ and $\mathrm{CO}_{2}$ fluxes from a subtropical mangrove swamp and their relationships with soil characteristics, Soil Biol. Biochem., 48, 175-181, https://doi.org/10.1016/j.soilbio.2012.01.029, 2012.

Conrad, R.: The global methane cycle: recent advances in understanding the microbial processes involved, Env. Microbiol. Rep., 1, 285-292, https://doi.org/10.1111/j.1758-2229.2009.00038.x, 2009.

Deemer, B. R., Harrison, J. A., Li, S., Beaulieu, J. J., Delsontro, T., Barros, N., Bezerra-Neto, J. F., Powers, S. M., Dos Santos, M. A., and Vonk, J. A.: Greenhouse Gas Emissions from Reservoir Water Surfaces: A New Global Synthesis, Bioscience, 66, 949964, https://doi.org/10.1093/biosci/biw117, 2016.

Department of Environment and Science, Queensland: Herbert drainage basin - facts and maps, WetlandInfo website, available at: https://wetlandinfo.des.qld.gov.au/wetlands/facts-maps/ basin-herbert/ (last access: 13 January 2021), 2013.

Department of Environment and Science, Queensland: State of the environment report, Total greenhouse gas emissions, available at: https://www.stateoftheenvironment. des.qld.gov.au/pollution/greenhouse-gas-emissions/

total-annual-greenhouse-gas-emissions (last access: 5 April 2021), 2016.

Ding, W. X., Cai, Z. C., and Tsuruta, H.: Cultivation, nitrogen fertilization, and set-aside effects on methane uptake in a drained marsh soil in Northeast China, Glob. Change Biol., 10, 18011809, https://doi.org/10.1111/j.1365-2486.2004.00843.x, 2004.

Drenovsky, R. E., Steenwerth, K. L., Jackson, L. E., and Scow, K. M.: Land use and climatic factors structure regional patterns in soil microbial communities, Global Ecol. Biogeogr., 19, 27-39, https://doi.org/10.1111/j.1466-8238.2009.00486.x, 2010.

Drexler, J. Z., de Fontaine, C. S., and Deverel, S. J.: The legacy of wetland drainage on the remaining peat in the Sacramento-San Joaquin Delta, California, USA, Wetlands, 29, 372-386, 2009.

Duarte, C. M., Losada, I. J., Hendriks, I. E., Mazarrasa, I., and Marbà, N.: The role of coastal plant communities for climate change mitigation and adaptation, Nat. Clim. Chang., 3, 961968, https://doi.org/10.1038/nclimate1970, 2013.

Fernandez-Bou, A. S., Dierick, D., Allen, M. F., and Harmon, T. C.: Precipitation-drainage cycles lead to hot moments in soil carbon dioxide dynamics in a Neotropical wet forest, Glob. Change Biol., 26, 5303-5319, https://doi.org/10.1111/gcb.15194, 2020.

Griggs, P. D.: Too much water: drainage schemes and landscape change in the sugar-producing areas of Queensland, 1920-90, Aust. Geogr., 49, 81-105, https://doi.org/10.1080/00049182.2017.1336965, 2018.

Grinham, A., Albert, S., Deering, N., Dunbabin, M., Bastviken, D., Sherman, B., Lovelock, C. E., and Evans, C. D.: The importance of small artificial water bodies as sources of methane emissions in Queensland, Australia, Hydrol. Earth Syst. Sci., 22, 52815298, https://doi.org/10.5194/hess-22-5281-2018, 2018.

Hirano, T., Segah, H., Kusin, K., Limin, S., Takahashi, H., and Osaki, M.: Effects of disturbances on the carbon balance of tropical peat swamp forests, Glob. Change Biol., 18, 3410-3422, https://doi.org/10.1111/j.1365-2486.2012.02793.x, 2012.

Hooijer, A., Page, S., Jauhiainen, J., Lee, W. A., Lu, X. X., Idris, A., and Anshari, G.: Subsidence and carbon loss in drained tropical peatlands, Biogeosciences, 9, 1053-1071, https://doi.org/10.5194/bg-9-1053-2012, 2012.

Hutchinson, G. L. and Mosier, A. R.: Improved Soil Cover Method for Field Measurement of Nitrous Oxide Fluxes, Soil Sci. Soc. Am. J., 45, 311-316, https://doi.org/10.2136/sssaj1981.03615995004500020017x, 1981.

IPCC: Supplement to the 2006 IPCC Guidelines for National Greenhouse Gas Inventories: Wetlands, edited by: Hiraishi, T, Krug, T., Tanabe, K., Srivastava, N., Baasansuren, J., Fukuda, M., and Troxler, T. G., Intergovernmental Panel on Climate Change, Geneva, 2013.

Jeffrey, L. C., Maher, D. T., Chiri, E., Leung, P. M., Nauer, P. A., Arndt, S. K., Tait, D. R., Greening, C., and Johnston, S. G.: Bark-dwelling methanotrophic bacteria decrease methane emissions from trees, Nat. Commun., 12, 2127, https://doi.org/10.1038/s41467-021-22333-7, 2021.

Johnson, A. K. L., Ebert, S. P., and Murray, A. E.: Distribution of coastal freshwater wetlands and riparian forests in the Herbert River catchment and implications for management of catchments adjacent the Great Barrier Reef Marine Park, Environ. Conserv., 26, 229-235, https://doi.org/10.1017/S0376892999000314, 1999.

Kauffman, J. B., Adame, M. F., Arifanti, V. B., Schile-Beers, L. M., Bernardino, A. F., Bhomia, R. K., Donato, D. C., Feller, I. C., Ferreira, T. O., Jesus Garcia, M. del C., MacKenzie, R. A., Megonigal, J. P., Murdiyarso, D., Simpson, L., and Hernández Trejo, H.: Total ecosystem carbon stocks of mangroves across broad global environmental and physical gradients, Ecol. Monogr., 90, e01405, https://doi.org/10.1002/ecm.1405, 2020.

Kavehei, E., Iram, N., Rezaei Rashti, M., Jenkins, G. A., Lemckert, C., and Adame, M. F.: Greenhouse gas emissions from stormwater bioretention basins, Ecol. Eng., 159, 106120, https://doi.org/10.1016/j.ecoleng.2020.106120, 2021.

Kettler, T. A., Doran, J. W., and Gilbert, T. L.: Simplified Method for Soil Particle-Size Determination to Accompany Soil-Quality Analyses, Soil Sci. Soc. Am. J., 65, 849-852, https://doi.org/10.2136/sssaj2001.653849x, 2001. 
Kiese, R. and Butterbach-Bahl, $\mathrm{K} .: \mathrm{N}_{2} \mathrm{O}$ and $\mathrm{CO}_{2}$ emissions from three different tropical forest sites in the wet tropics of Queensland, Australia, Soil Biol. Biochem., 34, 975-987, 2002.

Kirschke, S., Bousquet, P., Ciais, P., Saunois, M., Canadell, J. G., Dlugokencky, E. J., Bergamaschi, P., Bergmann, D., Blake, D. R., Bruhwiler, L., Cameron-Smith, P., Castaldi, S., Chevallier, F., Feng, L., Fraser, A., Heimann, M., Hodson, E. L., Houweling, S., Josse, B., Fraser, P. J., Krummel, P. B., Lamarque, J. F., Langenfelds, R. L., Le Quéré, C., Naik, V., O’Doherty, S., Palmer, P. I., Pison, I., Plummer, D., Poulter, B., Prinn, R. G., Rigby, M., Ringeval, B., Santini, M., Schmidt, M., Shindell, D. T., Simpson, I. J., Spahni, R., Steele, L. P., Strode, S. A., Sudo, K., Szopa, S., Van Der Werf, G. R., Voulgarakis, A., Van Weele, M., Weiss, R. F., Williams, J. E., and Zeng, G.: Three decades of global methane sources and sinks, Nat. Geosci., 6, 813-823, https://doi.org/10.1038/ngeo1955, 2013.

Knox, S. H., Sturtevant, C., Matthes, J. H., Koteen, L., Verfaillie, J., and Baldocchi, D.: Agricultural peatland restoration: Effects of land-use change on greenhouse gas $\left(\mathrm{CO}_{2}\right.$ and $\left.\mathrm{CH}_{4}\right)$ fluxes in the Sacramento-San Joaquin Delta, Glob. Change Biol., 21, 750765, https://doi.org/10.1111/gcb.12745, 2015.

Kögel-Knabner, I., Amelung, W., Cao, Z., Fiedler, S., Frenzel, P., Jahn, R., Kalbitz, K., Kölbl, A., and Schloter, M.: Biogeochemistry of paddy soils, Geoderma, 157, 1-14, https://doi.org/10.1016/J.GEODERMA.2010.03.009, 2010.

Kreuzwieser, J., Buchholz, J., and Rennenberg, H.: Emission of Methane and Nitrous Oxide by Australian Mangrove Ecosystems, Plant Biol., 5, 423-431, https://doi.org/10.1055/s-200342712, 2003.

Kristensen, E., Flindt, M. R., Ulomi, S., Borges, A. V., Abril, G., and Bouillon, S.: Emission of $\mathrm{CO} 2$ and $\mathrm{CH} 4$ to the atmosphere by sediments and open waters in two Tanzanian mangrove forests, Mar. Ecol. Prog. Ser., 370, 53-67, https://doi.org/10.3354/meps07642, 2008.

Krithika, K., Purvaja, R., and Ramesh, R.: Fluxes of methane and nitrous oxide from an Indian mangrove, Curr. Sci., 94, 218-224, 2008.

Kroeger, K. D., Crooks, S., Moseman-Valtierra, S., and Tang, J.: Restoring tides to reduce methane emissions in impounded wetlands: A new and potent Blue Carbon climate change intervention, Sci. Rep., 7, 11914, https://doi.org/10.1038/s41598-01712138-4, 2017.

Lehner, B. and Döll, P.: Development and validation of a global database of lakes, reservoirs and wetlands, J. Hydrol., 296, 1-22, https://doi.org/10.1016/j.jhydrol.2004.03.028, 2004.

Lenhart, K., Behrendt, T., Greiner, S., Steinkamp, J., Well, R., Giesemann, A., and Keppler, F.: Nitrous oxide effluxes from plants as a potentially important source to the atmosphere, New Phytol., 221, 1398-1408, https://doi.org/10.1111/nph.15455, 2019

Li, X. and Mitsch, W. J.: Methane emissions from created and restored freshwater and brackish marshes in southwest Florida, USA, Ecol. Eng., 91, 529-536, https://doi.org/10.1016/j.ecoleng.2016.01.001, 2016.

Liu, J. and Lai, D. Y. F.: Subtropical mangrove wetland is a stronger carbon dioxide sink in the dry than wet seasons, Agr. Forest Meteorol., 278, 107644, https://doi.org/10.1016/J.AGRFORMET.2019.107644, 2019.
Maher, D. T., Sippo, J. Z., Tait, D. R., Holloway, C., and Santos, I. R.: Pristine mangrove creek waters are a sink of nitrous oxide OPEN, Nat. Publ. Gr., 6, 25701, https://doi.org/10.1038/srep25701, 2016.

Maietta, C. E., Hondula, K. L., Jones, C. N., and Palmer, M. A.: Hydrological Conditions Influence Soil and Methane-Cycling Microbial Populations in Seasonally Saturated Wetlands, Front. Environ. Sci., 8, 593942, https://doi.org/10.3389/fenvs.2020.593942, 2020.

Mar Lynn, T., Ge, T., Yuan, H., Wei, X., Wu, X., Xiao, K., Kumaresan, D., San Yu, S., Wu, J., and Whiteley, A. S.: Soil Carbon-Fixation Rates and Associated Bacterial Diversity and Abundance in Three Natural Ecosystems, 73, 645-657, https://doi.org/10.1007/s00248-016-0890-x, 2017.

Martiny, J. B. H., Bohannan, B. J. M., Brown, J. H., Colwell, R. K., Fuhrman, J. A., Green, J. L., Horner-Devine, M. C., Kane, M., Krumins, J. A., Kuske, C. R., Morin, P. J., Naeem, S., Øvreås, L., Reysenbach, A. L., Smith, V. H., and Staley, J. T.: Microbial biogeography: Putting microorganisms on the map, Nat. Rev. Microbiol., 4, 102-112, https://doi.org/10.1038/nrmicro1341, 2006.

McGinn, S. M., Turner, D., Tomkins, N., Charmley, E., BishopHurley, G., and Chen, D.: Methane Emissions from Grazing Cattle Using Point-Source Dispersion, J. Environ. Qual., 40, 22-27, https://doi.org/10.2134/jeq2010.0239, 2011.

Melling, L., Goh, K. J., Kloni, A., and Hatano, R.: Is water table the most important factor influencing soil $\mathrm{C}$ flux in tropical peatlands, in: Peatlands in Balance, Proceedings of the 14th International Peat Congress, 2012.

Mitsch, W. J., Bernal, B., Nahlik, A. M., Mander, Ü., Zhang, L., Anderson, C. J., Jørgensen, S. E., and Brix, H.: Wetlands, carbon, and climate change, Landsc. Ecol., 28, 583-597, https://doi.org/10.1007/s10980-012-9758-8, 2013.

Morse, J. L. and Marcelo Ardón, E. S. B.: Greenhouse gas fluxes in southeastern U . S . coastal plain wetlands under contrasting land uses, Ecol. Appl., 22, 264-280, 2012.

Musenze, R. S., Werner, U., Grinham, A., Udy, J., and Yuan, Z.: Methane and nitrous oxide emissions from a subtropical estuary (the Brisbane River estuary, Australia), Sci. Total Environ., 472, 719-729, https://doi.org/10.1016/j.scitotenv.2013.11.085, 2014.

National Greenhouse Accounts Factors, Australian Government Department of Industry, Science, Energy and Resources: National Greenhouse Accounts Factors, available at: https://www.industry.gov.au/sites/default/files/2020-10/ national-greenhouse-accounts-factors-2020.pdf (last access: 9 August 2021), 2020.

Neubauer, S. C. Global Warming Potential Is Not an Ecosystem Property, Ecosystems, 1-11, https://doi.org/10.1007/s10021021-00631-x, 2021.

Nieveen, J. P., Campell, D. I., Schipper, L. A., and Blair, I. J.: Carbon exchange of grazed pasture on drained peat soil, Glob. Change Biol., 11, 607-618, https://doi.org/10.1111/j.13652486.2005.00929.x, 2005.

Oertel, C., Matschullat, J., Zurba, K., Zimmermann, F., and Erasmi, S.: Greenhouse gas emissions from soils - A review, Chem. Erde, 76, 327-352, https://doi.org/10.1016/j.chemer.2016.04.002, 2016.

Ollivier, Q. R., Maher, D. T., Pitfield, C., and Macreadie, P. I.: Punching above their weight: Large release of greenhouse gases 
from small agricultural dams, Glob. Change Biol., 25, 721-732, https://doi.org/10.1111/gcb.14477, 2019.

Pangala, S. R., Moore, S., Hornibrook, E. R. C., and Gauci, V.: Trees are major conduits for methane egress from tropical forested wetlands, New Phytol., 197, 524-531, https://doi.org/10.1111/nph.12031, 2013.

Peacock, M., Audet, J., Bastviken, D., Futter, M. N., Gauci, V., Grinham, A., Harrison, J. A., Kent, M. S., Kosten, S., Lovelock, C. E., Veraart, A. J., and Evans, C. D.: Global importance of methane emissions from drainage ditches and canals, Environ. Res. Lett., 16, 044010, https://doi.org/10.1088/17489326/abeb36, 2021.

Pinheiro, P. L., Recous, S., Dietrich, G., Weiler, D. A., Schu, A. L., Bazzo, H. L. S., and Giacomini, S. J.: $\mathrm{N}_{2} \mathrm{O}$ emission increases with mulch mass in a fertilized sugarcane cropping system, Biol. Fert. Soils, 55, 511-523, https://doi.org/10.1007/s00374019-01366-7, 2019.

Purvaja, R. and Ramesh, R.: Human impacts on methane emission from mangrove ecosystems in India, Reg. Environ. Change, 1, 86-97, 2000.

Purvaja, R., Ramesh, R., and Frenzel, P.: Plant-mediated methane emission from an Indian mangrove, Glob. Change Biol., 10, 1825-1834, https://doi.org/10.1111/j.1365-2486.2004.00834.x, 2004.

Reeves, S., Wang, W., Salter, B., and Halpin, N.: Quantifying nitrous oxide emissions from sugarcane cropping systems: Optimum sampling time and frequency, Atmos. Environ., 136, 123 133, https://doi.org/10.1016/j.atmosenv.2016.04.008, 2016.

Rezaei Rashti, M., Wang, W. J., Harper, S. M., Moody, P. W., Chen, C. R., Ghadiri, H., and Reeves, S. H.: Strategies to mitigate greenhouse gas emissions in intensively managed vegetable cropping systems in subtropical Australia, Soil Res., 53, 475484, https://doi.org/10.1071/SR14355, 2015.

Rezaei Rashti, M., Wang, W. J., Reeves, S. H., Harper, S. M., Moody, P. W., and Chen, C. R.: Linking chemical and biochemical composition of plant materials to their effects on $\mathrm{N} 2 \mathrm{O}$ emissions from a vegetable soil, Soil Biol. Biochem., 103, 502-511, https://doi.org/10.1016/j.soilbio.2016.09.019, 2016.

Rosentreter, J. A., Al-Haj, A. N., Fulweiler, R. W., and Williamson, P.: Methane and Nitrous Oxide Emissions Complicate Coastal Blue Carbon Assessments, Global Biogeochem. Cy., 35, e2020GB006858, https://doi.org/10.1029/2020GB006858, 2021.

Sahrawat, K. L.: Terminal electron acceptors for controlling methane emissions from submerged rice soils, Commun. Soil Sci. Plan., 35, 1401-1413, https://doi.org/10.1081/CSS120037554, 2004.

Saunois, M., Stavert, A. R., Poulter, B., Bousquet, P., Canadell, J. G., Jackson, R. B., Raymond, P. A., Dlugokencky, E. J., Houweling, S., Patra, P. K., Ciais, P., Arora, V. K., Bastviken, D., Bergamaschi, P., Blake, D. R., Brailsford, G., Bruhwiler, L., Carlson, K. M., Carrol, M., Castaldi, S., Chandra, N., Crevoisier, C., Crill, P. M., Covey, K., Curry, C. L., Etiope, G., Frankenberg, C., Gedney, N., Hegglin, M. I., Höglund-Isaksson, L., Hugelius, G., Ishizawa, M., Ito, A., Janssens-Maenhout, G., Jensen, K. M., Joos, F., Kleinen, T., Krummel, P. B., Langenfelds, R. L., Laruelle, G. G., Liu, L., Machida, T., Maksyutov, S., McDonald, K. C., McNorton, J., Miller, P. A., Melton, J. R., Morino, I., Müller, J., Murguia-Flores, F., Naik, V., Niwa, Y., Noce, S.,
O’Doherty, S., Parker, R. J., Peng, C., Peng, S., Peters, G. P., Prigent, C., Prinn, R., Ramonet, M., Regnier, P., Riley, W. J., Rosentreter, J. A., Segers, A., Simpson, I. J., Shi, H., Smith, S. J., Steele, L. P., Thornton, B. F., Tian, H., Tohjima, Y., Tubiello, F. N., Tsuruta, A., Viovy, N., Voulgarakis, A., Weber, T. S., van Weele, M., van der Werf, G. R., Weiss, R. F., Worthy, D., Wunch, D., Yin, Y., Yoshida, Y., Zhang, W., Zhang, Z., Zhao, Y., Zheng, B., Zhu, Q., Zhu, Q., and Zhuang, Q.: The Global Methane Budget 2000-2017, Earth Syst. Sci. Data, 12, 15611623, https://doi.org/10.5194/essd-12-1561-2020, 2020.

Schindlbacher, A., Zechmeister-Boltenstern, S., and ButterbachBahl, K.: Effects of soil moisture and temperature on $\mathrm{NO}, \mathrm{NO}_{2}$, and $\mathrm{N}_{2} \mathrm{O}$ emissions from European forest soils, J. Geophys. Res, 109, 17302, https://doi.org/10.1029/2004JD004590, 2004.

Shaaban, M., Peng, Q., Hu, R., Wu, Y., Lin, S., and Zhao, J.: Dolomite application to acidic soils: a promising option for mitigating $\mathrm{N}_{2} \mathrm{O}$ emissions, Environ. Sci. Pollut. R., 22, 1996119970, https://doi.org/10.1007/s11356-015-5238-4, 2015.

Solomon, S.: Climate Change: The Physical science Basis, Clim. Chang. Phys. Sci. Basis, available at: http://ci.nii.ac.jp/naid/ 20001628955/en/ (last access: 13 August 2021), 2007.

Sotomayor, D., Corredor, J. E., and Morell, J. M.: Methane flux from mangrove sediments along the southwestern coast of Puerto Rico, Estuaries, 17, 140-147, 1994.

Timilsina, A., Bizimana, F., Pandey, B., Kailash, R., Yadav, P., Dong, W., and $\mathrm{Hu}, \mathrm{C}$. : plants Nitrous Oxide Emissions from Paddies: Understanding the Role of Rice Plants, Plants, 9, 180, https://doi.org/10.3390/plants9020180, 2020.

Ussiri, D. and Lal, R.: Soil emission of nitrous oxide and its mitigation. Springer Science \& Business Media, Germany, 378, ISBN 978-94-007-5364-8, 2012.

Veenendaal, E. M., Kolle, O., Leffelaar, P. A., Schrier-Uijl, A. P., Van Huissteden, J., Van Walsem, J., Möller, F., and Berendse, F.: $\mathrm{CO}_{2}$ exchange and carbon balance in two grassland sites on eutrophic drained peat soils, Biogeosciences, 4, 1027-1040, https://doi.org/10.5194/bg-4-1027-2007, 2007.

Whalen, S.: Biogeochemistry of methane exchange between natural wetlands and the atmosphere, Environ. Eng. Sci., 22, 73-94, https://doi.org/10.1089/ees.2005.22.73, 2005.

Whiting, G. J. and Chanton, J. P.: Greenhouse carbon balance of wetlands: Methane emission versus carbon sequestration, Tellus B, 53, 521-528, https://doi.org/10.3402/tellusb.v53i5.16628, 2001.

Xu, C., Han, X., Ru, S., Cardenas, L., Rees, R. M., Wu, D., Wu, W., and Meng, F.: Crop straw incorporation interacts with $\mathrm{N}$ fertilizer on $\mathrm{N} 2 \mathrm{O}$ emissions in an intensively cropped farmland, Geoderma, 341, 129-137, https://doi.org/10.1016/J.GEODERMA.2019.01.014, 2019.

Yvon-Durocher, G., Montoya, J. M., Woodward, G., Jones, J. I., and Trimmer, M.: Warming increases the proportion of primary production emitted as methane from freshwater mesocosms, Glob. Change Biol., 17, 1225-1234, https://doi.org/10.1111/j.13652486.2010.02289.x, 2011.

Zaehle, S. and Dalmonech, D.: Carbon-nitrogen interactions on land at global scales: Current understanding in modelling climate biosphere feedbacks, Curr. Opin. Env. Sust., 3, 311-320, https://doi.org/10.1016/j.cosust.2011.08.008, 2011. 